\title{
SPECIFIC STRUCTURAL-FUNCTIONAL ROLE OF THE PRONOUNCED NEGATIVE MOLECULAR CHARGE OF THE STURGEON GONADOTROPIN $\beta$-SUBUNIT
}

\author{
Henriks Zenkevičs and Vija Vose \\ Institute of Biology, University of Latvia, Miera iela 3, Salaspils, LV-2169, LATVIA; \\ zenkevics@email.lubi.edu.Iv
}

Contributed by Henriks Zenkevičs

\begin{abstract}
Free negatively charged carboxyl groups $(\mathrm{COOH})$ were selectively modified (neutralised) in sturgeon (Acipenser güldenstädti $\mathrm{Br}$ ) gonadotropic hormone (GTH) $\beta$-subunit ( $\beta G T H)$. Eight $\mathrm{COOH}$ groups were neutralised by reaction with glycine ethyl ester. Investigation of modified $\beta G T H$ showed that specific immunoactivity with antiserum raised against standard $\beta G T H$ was completely lost. Analysis of CD spectra and the content of secondary structure elements of standard and modified $\beta G T H$ did not indicate any considerable differences. Investigation of reassociated $\alpha-\beta$ dimer comprising standard $\alpha G T H$ and modified $\beta G T H$ showed that hormonal activity was completely lost while immunoreactivity was lowered by about $30 \%$ in comparison with that of the standard subunit $\alpha-\beta$ dimer. It was concluded that eight free $\mathrm{COOH}$ groups located on the surface of $\beta G T H$ are the main structural components of the species-specific antigenic determinant groups of the subunit, but are not directly involved in either maintaining the conformation of the subunit nor in its ability to interact with the native counterpart subunit. $\mathrm{COOH}$ groups, as bearers of the negative charge located on the surface of $\beta G T H$, play a decisive role in the specific hormonal activity of GTH determined by oocyte maturation tests. Free $\mathrm{COOH}$ groups are included in the effector zones (active sites) of GTH dimer molecule responsible for the stereospecific interaction with the test-oocyte membrane hormone-sensitive binding (receptor) sites to induce the biological effects.
\end{abstract}

Key words: sturgeon fish gonadotropic hormone, $\beta$-subunit, chemical modification, CD-spectroscopy, gonadotropic and immunologic properties.

\section{INTRODUCTION}

Gonadotropic hormone (GTH, gonadotropin; $25 \mathrm{kDa}$ ) of sturgeon Acipenser güldenstädti Br., like mammalian gonadotropins, has heterodimeric molecular structure built of two complementary non-covalently bonded $\alpha$ and $\beta$ subunits ( $\alpha \mathrm{GTH}$ and $\beta \mathrm{GTH})$ (Burzawa-Gerard et al., 1980; Зенкевич и др., 1982; Zenkevičs, 1994). Individual $\alpha \mathrm{GTH}$ and $\beta$ GTH have no hormonal function. Specific biological activity typical for the native hormone is expressed only after complementary self-reassociation of the counterpart subunits in the $\alpha-\beta$ dimer structure. Reassociated from the subunits, GTH dimer usually maintains up to $100 \%$ of immunoreactivity and by about $70 \%$ of hormonal function typical of the native hormone.

In the course of comparative investigations of $\alpha \mathrm{GTH}$ and $\beta \mathrm{GTH}$ it was found that the subunits differed considerably from each other by their negative molecular charge. The electrophoretic mobility (Rf) of $\beta$ GTH (Rf $0.41-0.58$ ) in $7.5 \%$ polyacrylamide gel towards the anode was considerably higher than that of the positively charged $\alpha \mathrm{GTH}$ (Rf 0.05-0.15) (Zenkevičs, 1994; Zenkevičs et al., 2003). This indicated that $\alpha \mathrm{GTH}$ (three $\mathrm{COOH}$ groups) contains a predominance of positive molecular charge, unlike $\beta \mathrm{GTH}$. Also, as it was previously shown, $\beta$ GTH has a rigid conformation stabilised by six intramolecular S-S-bonds, while the conformationally flexible $\alpha \mathrm{GTH}$ contains only one S-S-bond (Zenkevičs, 1994).

Comparative investigation of the structural-functional role of gonadotropin subunits provided evidence that $\alpha \mathrm{GTH}$ is highly conserved within different higher and lower vertebrate species, including fish, while $\beta$ GTH differs and imparts the species-specificity to the $\alpha-\beta$ dimeric structure of the hormone (Licht et al., 1977; Pierce and Parsons, 1981; Burzawa-Gerard, 1982). The same was found in studies of properties of cross-recombinants of the counterpart subunits from systematically very distant sturgeon GTH and pig LH (Зенкевич и др.1982; Zenkevičs et al., 1999). On the basis of these findings we supposed that the pronounced negative molecular charge and the conformational rigidity of the sturgeon $\beta$ GTH may serve as a core imparting charge, three-dimensional spatial structure and the biological properties to the $\alpha-\beta$ heterodimeric molecule of the hormone. 
The aim of the present work was to employ selective chemical modification of the accessible free $\mathrm{COOH}$ groups of Asp and Glu located in the $\beta$ GTH to elucidate their possible role in maintaining the conformation of the subunit and the species-specific functional properties of the $\alpha-\beta$ dimer hormone molecule.

\section{MATERIALS AND METHODS}

Individual $\alpha \mathrm{GTH}$ and $\beta \mathrm{GTH}$ of highly purified sturgeon GTH (Зенкевич, 1992) were isolated by ion-exchange chromatography on SE-Sephadex C-25 in $0.025 \mathrm{M}$ acetate buffer at $\mathrm{pH} 4.9$, after GTH dissociation into subunits in 8 M urea according to Hennen et al. (1971).

Self-reassociation or recombination of the counterpart subunits was carried out in saline $(0.9 \% \mathrm{NaCl})$ at room temperature $(12 \mathrm{~h})$ at a total protein concentration of about $0.2 \%$, using the subunits in an equimolar ratio.

Polyacrylamide gel $(7.5 \%)$ electrophoresis (PAGE) was carried out in gel slabs $(0.4 \times 9 \times 10 \mathrm{~cm})$, using TRIS-Gly buffer solution at $\mathrm{pH} 8.9$ (Davis, 1962). Protein bands were stained with Coomassie Brilliant blue R-250.

Free $\mathrm{COOH}$ groups of $\beta \mathrm{GTH}$ were modified by glycine ethyl ester (Gly-OEt.HCl) in the presence of water soluble 1-ethyl-3(3-dimethylaminopropyl) carbodiimide (Serva) at $\mathrm{pH} 4.8$ in distilled water for $30 \mathrm{~min}$ at room temperature according to the procedure described earlier (Eyl et al., 1970; Faith and Pierce, 1975). In such a way the negative charge of free carboxyl groups of the subunit were converted to their O-glycine ethyl esters (neutralised). The reaction was stopped and modified subunit was separated from the reaction by-products on minicolumns $(0.9 \times 10.5 \mathrm{~cm})$ of Sephadex C-25 in 2\% acetic acid and lyophilised. The number of modified $\mathrm{COOH}$ groups of the $\beta \mathrm{GTH}$ was determined by amino acid analysis (Mikrotehna Praha, Czech Rep.).

To produce antisera against GTH and $\beta$ GTH young rabbits were injected subcutaneously and intramuscularly with the preparations (0.2 mg/injection) in saline using complete Freund's adjuvant (Calbiochem, USA) for ten weeks.

Double immunodiffusion tests in $1 \%$ agar gel (Bacto-agar Difco, USA) in veronal buffer (ionic strength 0.05, $\mathrm{pH} 8.6$ ) were performed by a classical procedure (Ouchterlony, 1958) using polyclonal monovalent antisera. The immunoreactivity as a percent of the standard and modified preparations was calculated as the inverse proportion between the numbers of active double dilutions.

The frog Rana temporaria L. oocyte in vitro maturation test (Thornton, 1971) was used to evaluate (to compare) the hormonal activity of the reassociated a- $\beta$ dimers comprising $\mathrm{COOH}$-modified or intact $\beta \mathrm{GTH}$. The activity was expressed as the minimal dose of the tested hormone preparation that produced $50 \%$ test-oocyte maturation (D50).
$\mathrm{CD}$ spectra of the standard and $\mathrm{COOH}$-modified $\beta \mathrm{GTH}$ were registered on a Jasco J-710 spectropolarimeter over the wavelength range from 180 to $250 \mathrm{~nm}$ at $22-25^{\circ} \mathrm{C}$, in phosphate buffer, $\mathrm{pH}$ 7.0. The spectropolarimeter was calibrated by epiandrosterone and 10-camphor-sulphonic acid standards. For recording of spectra, 0.1-0.01 cm Helma quartz cells were used. The concentration of protein in the solution was $10^{-3}-10^{-4} \mathrm{M}$. CD data are given in units of molar ellipticity per amino acid residue of an average relative molecular mass 108. The content of various secondary structures in the subunits was calculated using the CDPro CONTINLL software (Sreerama et al., 1999; Whitmore and Wallace, 2004; Lees et al., 2006). In our case the CD spectra of 29-48 proteins were used for calculation of the secondary structural elements.

\section{RESULTS}

Amino acid analysis of COOH-modified (etoxyglycylated) $\beta$ GTH showed that eight free accessible carboxyl groups located on the surface of the subunit were modified and converted to neutral ones. Also, it was found by additional amino acid analysis that the number of modified $\mathrm{COOH}$ groups in $\beta \mathrm{GTH}$ did not increase after 20 minutes of interaction with the modifying reagent. The modification (neutralisation) of $\beta \mathrm{GTH}\left(\beta \mathrm{GTH} \mathrm{mod}_{\mathrm{mod}}\right)$ significantly decreased its electrophoretic mobility(Rf ) 0.03-0.12, in comparison with that of standard intact $\beta \mathrm{GTH}_{\mathrm{st}}(0.41-0.58)$ (Fig. 1).

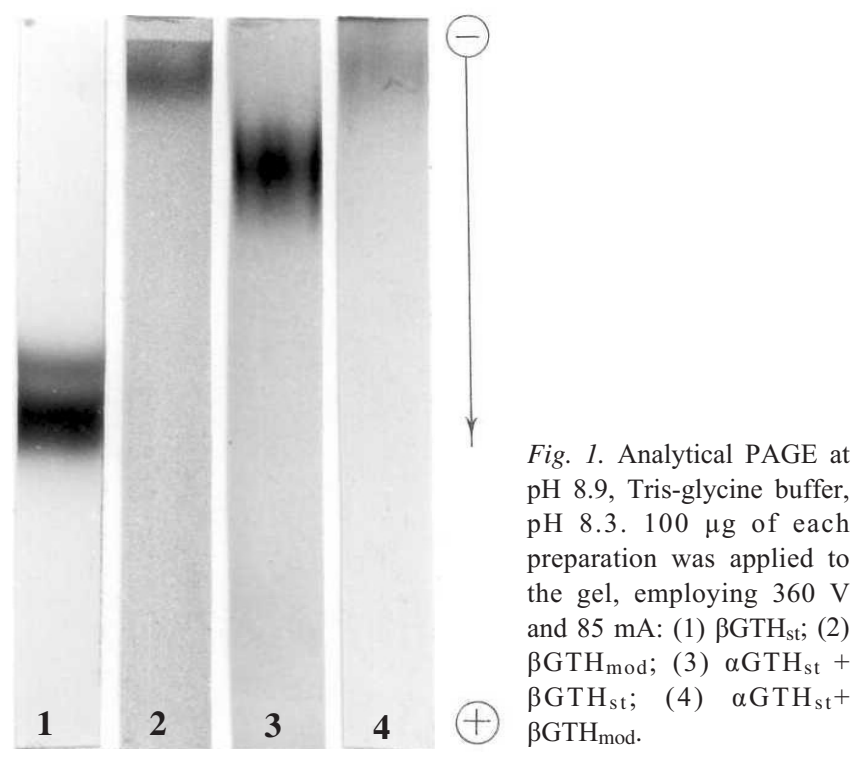

Comparison of the immunoreactivity of $\beta \mathrm{GTH}_{\bmod }$ and $\beta \mathrm{GTH}_{\text {st }}$ in double immunodiffusion tests using $\beta \mathrm{GTH}_{\mathrm{st}}$ antiserum (stepwise two-fold dilutions of the tested antigens) showed that $\beta \mathrm{GTH}_{\text {mod }}$ did not interact with the antibodies raised against standard subunit $\beta \mathrm{GTH}_{\mathrm{st}}$.

$\beta \mathrm{GTH}_{\text {st }}$ was recombined with intact $\alpha \mathrm{GTH}$ to produce dimer $\alpha \mathrm{GTH}_{\mathrm{st}}+\beta \mathrm{GTH}$ mod by self-reassociation of both counterpart subunits. This approach was used to elucidate the possible structure-functional impact caused by neutralisation of the negative molecular charge of the subunit on 
both the specific hormonal function and immunoreactivity of the dimer struture $\alpha \mathrm{GTH}_{\mathrm{st}}+\beta \mathrm{GTH}_{\text {mod }}$, in comparison with that of the control dimer $\alpha \mathrm{GTH}_{\mathrm{st}}+\beta \mathrm{GTH}_{\mathrm{st}}$ (Table 1). As seen, by the biological properties of the recombined dimers in the comparative double immunodiffusion test with the standard GTH antiserum (Table 1), the substitution of the native $\beta$ GTH in the $\alpha-\beta$ dimer by the $\beta \mathrm{GTH}_{\text {mod }}$ lowered the dimer immunoreactivity by $25 \%$ while the specific hormonal function lacked completely.

Table 1

BIOLOGICAL PROPERTIES OF REASSOCIATED $\alpha-\beta$ DIMERS COMPRISING STANDARD AND COOH-MODIFIED $\beta$-SUBUNIT

\begin{tabular}{ccccc}
\hline Preparation & Antiserum & $\begin{array}{c}\text { Immunore- } \\
\text { activity, } \%\end{array}$ & $\begin{array}{c}\text { Hormonal } \\
\text { activity, } \%\end{array}$ \\
\hline$\alpha$ GTHst $+\beta$ GTHst & GTH & 100 & 100 \\
$\alpha$ GTHst $+\beta$ GTHmod & GTH & 75 & 0
\end{tabular}

st - standard; mod. - modified COOH-groups

Comparative PAGE of $\alpha \mathrm{GTH}_{\mathrm{st}}+\beta \mathrm{GTH}_{\mathrm{st}}$ and $\alpha \mathrm{GTH}_{\mathrm{st}}+$ $\beta \mathrm{GTH}_{\text {mod }}$ indicated that Rf of $\alpha \mathrm{GTH}_{\mathrm{st}}+\beta \mathrm{GTH}_{\text {mod }}$ considerably decreased toward the anode ( $\operatorname{Rf} 0.02-0.13$ ) in comparison with that of the standard subunit dimer $\alpha \mathrm{GTH}_{\mathrm{st}}+$ $\beta \mathrm{GTH}_{\mathrm{st}}(0.14-0.28)$ (Fig. 1). Each of the compared reassociated dimers formed a massive and compact electrophoretic band. Also, Rf of $\beta G_{\text {THod }}(0.03-0.11)$ decreased sharply in comparison with that of $\beta \mathrm{GTH}_{\mathrm{st}}(0.41-0.58)$ (Fig. 1).

CD spectra (Fig. 2) indicate that the conformation of $\beta \mathrm{GTH}_{\mathrm{st}}$ and $\beta \mathrm{GTH} \mathrm{Hod}_{\text {mod }}$ is characterised by a negative band around 193-197 $\mathrm{nm}$ and a shoulder (or two minor negative bands) at 205 and $215 \mathrm{~nm}$ that is weakly expressed. The negative Cotton effect around $195 \mathrm{~nm}$ is close to the well known negative band of the random coil at $198 \mathrm{~nm}$, while the shoulder and the negative band (around 205 and 215 $\mathrm{nm}$ ) might be due to the contribution of the $\beta$-structures influenced by minor content of the $\alpha$-helix (Lees et al., 2006).

The results of the calculations and the shape of measured CD spectra indicated that there were no considerable distinctions between the content of various secondary structure elements of $\beta \mathrm{GTH}_{\text {mod }}$ and $\beta \mathrm{GTH}_{\text {st }}$ (Table 2).

\section{DISCUSSION}

Electrophoresis of $\beta \mathrm{GTH}_{\text {mod }}$ showed that etoxyglycylation of eight free accassible $\mathrm{COOH}$ groups resulted in a sharply declined negative charge of the modified subunit. PAGE indicated that $\mathrm{Rf}$ of the $\beta \mathrm{GTH}_{\text {mod }}(0.03-0.12)$, unlike the $\beta$ $\mathrm{GTH}_{\mathrm{st}}(0.41-0.58)$, was very close to that of the positively charged $\alpha \mathrm{GTH}_{\mathrm{st}}(0.05-0.15)$ (Zenkevics et al., 2003). Immunodiffusion tests with the $\beta \mathrm{GTH}_{\mathrm{st}}$ antiserum showed

Table 2

CONTENT OF SECONDARY STRUCTURAL ELEMENTS (\%) OF STANDARD AND COOH-MODIFIED $\beta$-SUBUNITS

\begin{tabular}{l|c|c|c|c}
\hline Preparation & $\alpha^{*}$ & $\beta^{*}$ & $\beta \mathrm{t}^{*}$ & $\mathrm{R}^{*}$ \\
\hline$\beta \mathrm{GTHst}$ & 1.9 & 24.7 & 15.2 & 58.2 \\
$\beta$ GTHmod & 2.3 & 24.2 & 14.3 & 59.2
\end{tabular}

${ }^{*} \alpha, \alpha$-helix; $\beta, \beta$-strand; $\beta_{\mathrm{t}}, \beta$-turn; $\mathrm{R}$ - random coil; st, standard; mod, modified $\mathrm{COOH}$-groups.

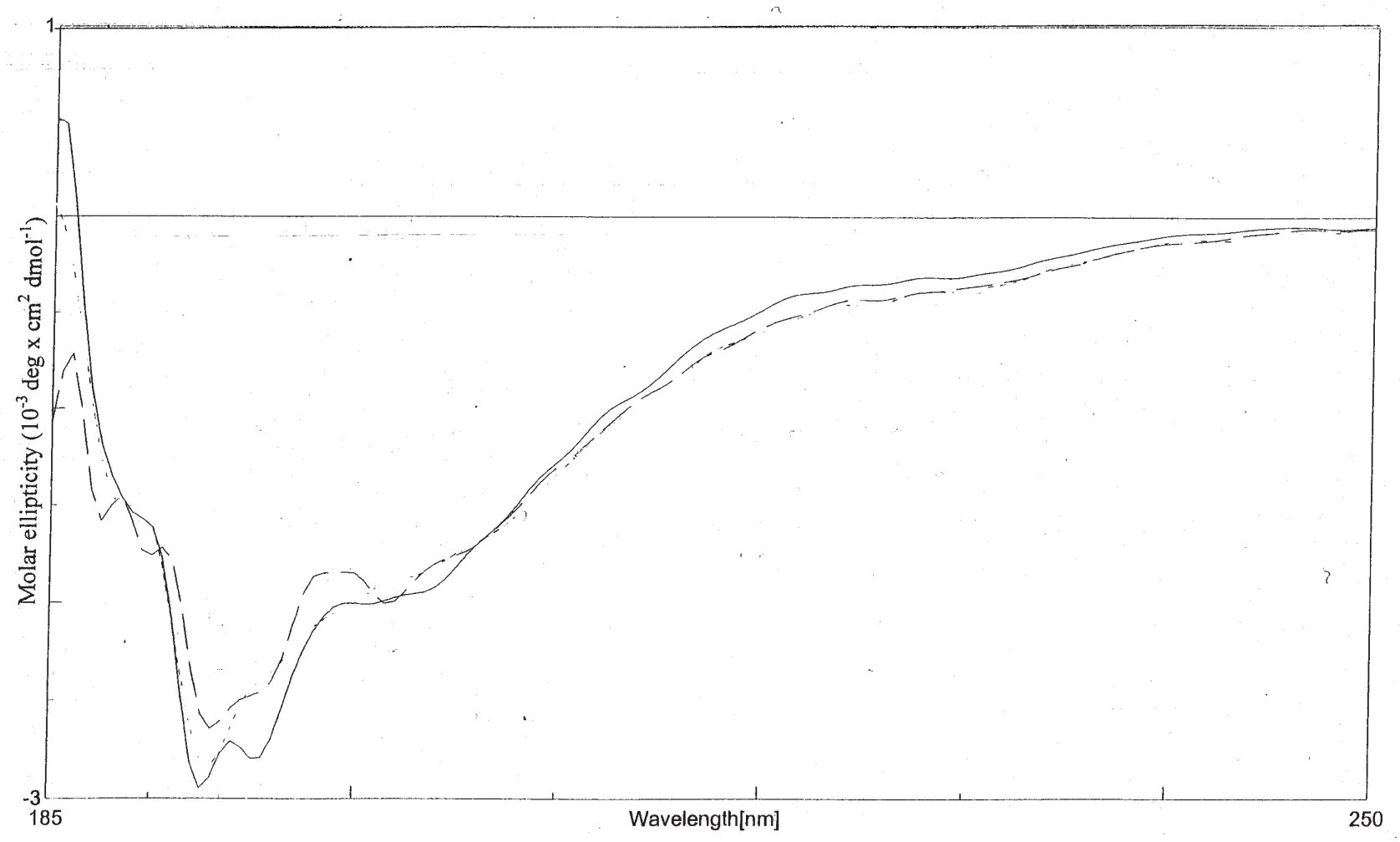

Fig. 2. CD spectra of sturgeon GTH $\beta_{\text {st }}(\longrightarrow), \beta_{\bmod }(---)$. 
that $\beta \mathrm{GTH}_{\text {mod }}$ was completely inactive. In other words, antibodies specific for $\beta \mathrm{GTH}_{\text {st }}$ cannot recognise $\beta \mathrm{GTH}_{\text {mod. }}$ This quite clearly shows that the neutralisation of carboxyl groups may play a considerable role in sustaining the structure of the antigenic determinant groups of the subunit responsible for the stereospecific interaction with the active

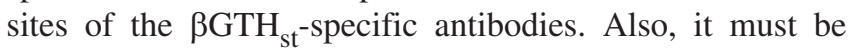
taken in consideration that the neutralisation of eight $\mathrm{COOH}$ groups located on the surface of the subunit may also produce a considerable redistribution of the surface charge of the modified subunit, which may cause an indirect impact on the thre-dimensional spatial structure and cause some deterioration in the site (determinants) configuration responsible for the immunospecificity of the subunit. This may account for lack of the specific immunoreactivity of the $\beta \mathrm{GTH}_{\text {mod }}$ typical of the $\beta \mathrm{GTH}_{\text {st. }}$

CD-spectroscopy studies showed that the removal of the negative charges of $\beta \mathrm{GTH}_{\mathrm{st}}$ did not produce any considerable shifts or appreciable distortion in spatial structure of the modified subunit, in comparison with that of the intact standard subunit (Fig. 2, Table 2). In order to determine whether $\beta \mathrm{GTH}_{\text {mod }}$ can interact with its counterpart $\alpha \mathrm{GTH}_{\mathrm{st}}$ to form stable $\alpha-\beta$ dimer structure typical of GTH, both counterpart subunits were submitted to self-reassociation. Investigation of the obtained dimer $\alpha \mathrm{GTH}_{\mathrm{st}}+\beta \mathrm{GTH}_{\text {mod }}$ in PAGE tests showed quite clearly that the modified dimer was stable (Fig. 1). This also indicated that $\beta G T H_{\text {mod }}$ on the whole retained its native configuration and complementarity of the sites responsible for subunit-subunit interaction (reassociation), structural stability of the $\alpha-\beta$ heterodimer and stereospecificity of its active sites responsible for the specific interaction with the native counterpart $\alpha \mathrm{GTH}$. Based on this finding, it is apparent that modified $\mathrm{COOH}$ groups of $\beta \mathrm{GTH}$ are not directly involved in the subunitsubunit interactions and in the formation of the three-dimensional functionally active structure recogniseable by active sites of standard GTH antibodies. However, even minimal distortions of the three-dimensional structure of stereocomplementary interacting protein structures may produce certain shifts in their specific biological function.

Immunoreactivity tests with standard GTH antiserum in double diffusion reactions showed that immunoreactivity of the hybrid molecule $\alpha \mathrm{GTH}_{\mathrm{st}}+\beta \mathrm{GTH}_{\text {mod }}$ decreased at least by $25 \%$ in comparison with that of the control $\alpha \mathrm{GTH}_{\mathrm{st}}+$ $\beta \mathrm{GTH}_{\mathrm{st}}$ (Table 1). Immunoidentity tests using standard GTH antiserum indicated partial identity (spur) between these two preparations. This means that the complementary interaction of the $\beta \mathrm{GTH}_{\text {mod }}$ with the $\alpha \mathrm{GTH}_{\text {st }}$ produced a certain incompatibility of the antigenic determinant groups in obtained hybrid dimer $\alpha-\beta$ structure, in comparison with that of the standard dimer.

The present results show that the neutralised eight negatively charged free carboxyl radicals were not critical for the stability of the native three-dimensional spatial structure of the subunit necessary for the recognition of the species-stereospecific interaction sites of the standard $\alpha \mathrm{GTH}$ to form stable dimer structure typical for the hormone On the other hand, comparison of the immunoreactivity of $\beta \mathrm{GTH}_{\mathrm{st}}$ and $\beta \mathrm{GTH}_{\text {mod }}$ using $\beta \mathrm{GTH} \mathrm{st}_{\mathrm{st}}$ antiserum indicated that the modified $\beta$ GTH was inactive. This showed quite clearly that the free $\mathrm{COOH}$ radicals are critical for the immunologic activity of the $\beta \mathrm{GTH}$. Based on this finding, it is apparent that $\mathrm{COOH}$ radicals may be inferred to be essential structure elements of the antigenic determinant groups of the $\beta \mathrm{GTH}$.

The comparative evaluation of hormonal activity showed (Table 1) that the modified recombinant $\alpha \mathrm{GTH}_{\mathrm{st}}+$ $\beta \mathrm{GTH}_{\text {mod }}$ was completely inactive.

This indicates that eight free $\mathrm{COOH}$ groups, located on the surface of the subunit, have direct importance for the specific hormonal function and are much less critical for the immunologic function of the dimer structure of the hormone.

The ability of the standard GTH antiserum to interact with the recombinant $\alpha$ GTHst $+\beta$ GTHmod in the immunospecific double diffusion tests indicated that the modification of the eight $\mathrm{COOH}$ groups of the $\beta \mathrm{GTH}$ did not prevent the formation of the $\alpha-\beta$ dimer structure typical of the hormone and are recognisable by the active sites of standard GTH antibodies.

However, these data allow to conclude that the modified $\mathrm{COOH}$ groups are not directly involved in the subunitsubunit interactions and in the formation of functionaly active three-dimensional structure of the recombinant.

The conformation of the investigated recombinant $\alpha \mathrm{GTH}$ st $+\beta$ GTHmod, comprising $\beta$ GTHmod, is quite closely related to that of the standard GTH, as indicated by antigen-antibody immunospecific interaction that necessitates quite close stereospecific fit between the antigenic determinant groups of the modified antigen $\alpha$ GTHst $+\beta$ GTHmod and the standard GTH in immunorection with active sites of the standard GTH antibodies.

Regarding hormonal activity, even minimal distortions of the three-dimensional structure of protein-like bioregulators may alter their functional (effector) group disposition on the molecular surface, causing considerable shifts in their ability to interact with the hormone-specific receptor sites of the cell membrane to induce the hormonal effects. The results also support our previous findings that the immunological properties of sturgeon GTH are much less vulnerable than its specific hormonal function (Зенкевич и др., 1992; Зенкевич, 1992).

Based on these findings it can be concluded that the eight free $\mathrm{COOH}$ groups located on the surface of $\beta \mathrm{GTH}$ are main structural components of the species-specific antigenic determinant groups of the subunit, but are not directly involved in both maintaining the conformation of the subunit and in its ability to interact with the native counterpart subunit. $\mathrm{COOH}$ groups of $\beta \mathrm{GTH}$, as bearers of the main negative charge potential located on the surface of the hormone molecule, play a decisive role in the specific hormonal ac- 
tivity of GTH at the hormone-competent cell level. The obtained results showed that free $\mathrm{COOH}$ groups are directly involved in the formation of the effector zones (active sites) of GTH dimer molecule responsible for the stereospecific interaction with the test-oocyte membrane hormone-sensitive binding (receptor) sites to induce the gonadotropic effects. Based on these findings, it is apparent that the pronounced negative molecular charge and the conformational rigidity of the $\beta$ GTH may serve as a molecular core imparting the molecular charge disposition and species specific features of the three-dimensional spatial structure of the $\alpha \mathrm{GTH}$ essential for the gonadotropic function of the hormone molecule.

\section{ACKNOWLEDGEMENTS}

This work was supported by the Latvian Council of Science, grant 09.1550 .

\section{REFERENCES}

Burzawa-Gerard, E. (1982). Chemical data on pituitary gonadotropins and their implication to evolution. Canad. J. Fisheries Aquat. Sci., 39, 80-91.

Burzawa-Gerard, E., Dufour, S., Fontaine, Y. A. (1980). Relations immunologiques entre les hormones glycoproteiques hypophysaires de poissons et de mammiferes ainsi qu'entre leurs sous-unites $\alpha$ et $\beta$. Gen. Comp. Endocrinol., 41, 199-211.

Davis, B. J. (1962). Disc Electrophoresis. Nr. 4. Rochester, N.Y.: Eston Kodak Co. 15 pp.

Eyl, A., Inagami, T. (1970). Modification of carboxyl groups in the active site of trypsin. Biochim. Biophys. Res. Commun., 38, 149-155.

Faith, M. R., Pierce, J. G. (1975).The carboxylic acid groups of bovine luteinizing hormone (The effect of their modification on receptor site binding and subunit interaction). J. Biol. Chem., 250 (17), 6923-6929.

Hennen, G., Prusik, Z., Maghuin-Rogister, G. (1971). Porcine luteinizing hormone and its subunits. Eur. J. Biochem., 18, 376-383.

Lees, J. G., Miles, A. J., Wien, F., Wallace, B. A. (2006). A reference database for circular dichroism spectroscopy covering fold and secondary structure space. Bioinformatics, 22 (16),1955-1962.
Licht, P., Papkoff, H., Farmer, S. W., Muller, C. H., Tsui, H. W., Crews, D. (1977). Recent Progr. Hormone Res., 33, 169-248.

Ouchterlony, O. (1958). Diffusion-in-gel methods for immunological analyses. Progr. Allergy, 5, 1-6.

Pierce, J. G., Parsons, T. F. (1981). Glycoprotein hormones: Structure and function. Ann. Rew. Biochem., 50, 465-495.

Sreerama, N., Venyaminov, S. Y., Woody, R. W. (1999). Estimation of the number of alpha-helical and beta-strand segments in proteins using circular dichroism spectroscopy. Protein Sci., 8, 370-380.

Thornton, V. F. (1971). A bioassay for progesterone and gonadotropins based on meiotic division of Xenopus oocytes in vitro. Gen. Comp. Endocrinol., 16, 599-605.

Whitmore, L., Wallace, B. A. (2004). DICHROWEB, an online server of protein secondary structure analyses from circular dichroism spectroscopic data. Nucleic Acid Res., 32, W668-W673.

Zenkevičs, H. (1994). Fish gonadotropic hormone: Structural-functional investigations. Proc. Latvian Acad. Sci., Section B, 48 (5/6), 82-88.

Zenkevičs, H., Vose, V., Būcena, A. (1999). Substitution of native subunits in sturgeon gonadotropin. Proc. Latvian Acad. Sci., Section B, 53 (5), 261-264.

Zenkevičs, H., Vose, V., Būcena, A. (2003). Functional role of tryptophan residues in sturgeon gonadotropic hormone. Proc. Latvian Acad. Sci., Section B, 57 (5), 187-190.

Зенкевич Г. А. (1992). Гонадотропныцй гормон рыб: получение и свойства [Fish Gonadotropic Hormone: Isolation and Properties]. Рига: Зинатне. 224 с. (in Russian).

Зенкевич Г. А., Арбатский Н. П., Сланке В. П., Желтова А. О., Деревицкая В. А. (1992). Структура углеводных цепей димерной молекулы и отдельных субъединиц гонадотропина русского осетра [Structure of the carbohydrate chains of the dimeric molecule and individual subunits of the Russian sturgeon gonadotropin]. Биоорган. хим., 18, 226-234 (in Russian).

Зенкевич Г. А., Кирстукас И. П., Лаце 3. М., Сланке В. П., Валдман А. Р. (1982). Получение субъединиц гонадотропного гормона русского осетра (Acipenser güldenstädti Br.) и севрюги (Acipenser stellatus Pall.) и оценка их гормональной активности и иммунохимических свойств до и после реассоциации [Isolation of Russian sturgeon and starred sturgeon gonadotropin subunits and investigation of its hormonal and immunochemical properties before and after reassociation]. Доклады Академии наук СССР, 268 (1), 249-251 (in Russian).

\section{STORES GONADOTROPĪNA IZTEIKTI NEGATĪVI LĀDĒTĀS $\beta$ SUBVIENĪBAS İPAŠĀ STRUKTŪRFUNKCIONĀLĀ LOMA}

Stores $\beta$ subvienībai $(\beta \mathrm{GTH})$, atškirīibā no $\alpha \mathrm{GTH}$, ir raksturīgs izteikti negatīvs molekulārais lādiṇš. Selektīvās k̦īmiskās modifikācijas cel̦ā $\beta$ GTH izdevās neitralizēt visas astoṇas brīvās COOH grupas. Modificētā subvienība pilnībā zaudēja spēju mijiedarboties ar standartsubvienības antivielām. Krasi samazinājās tās elektroforētiskā virzība uz anodu. Taču CD spektroskopijas pētījumi liecināja, ka modifikācija nav radījusi būtiskas izmainas $\beta$ GTH otrējā struktūrā. Modificētā $\beta$ GTH spēja reasociēties ar natīvo $\alpha$ GTH, veidojot elektroforētiski stabilu $\alpha-\beta$ dimēru, kura imūnreaktivitāte salīdzinājumā ar intakto subvienību $\alpha-\beta$ dimēru izrādījās par $30 \%$ zemāka imūntestos ar GTH antivielām. Taču tās hormonaktivitāte bija pilnībā zudusi. Secināts, ka brīvām COOH grupām ir būtiska nozīme $\beta$ GTH antigēno determinantu struktūras veidošanā, bet to loma subvienību specifiskās komplementārās mijiedarbības procesā nav īpaši nozīmīga. Pētījuma rezultāti rāda, ka brīvajām $\mathrm{COOH}$ grupām ir ìpaša nozīme hormona dimērmolekulas efektorajās zonās jeb aktīvajos centros, kas nodrošina GTH molekulas stereospecifisko mijiedarbību ar olšūnu membrānreceptoriem, tādējādi inducējot gonadotropā procesa norisi olšūnās. 